\title{
Pengoptimuman Tindak Balas Penghidrogenan Getah Asli Cecair melalui Kaedah Rangsangan Permukaan
}

(Liquid Natural Rubber Hydrogenation Optimization Reaction through Response Surface Methods)

\author{
FAZIRA FIRDAUS, NUR HANIS AdILA AZHAR, MOHAMAD SHAHRUl FIZREE IDRIS \& SiTI FAIRUS M. YUSOFF*
}

\begin{abstract}
ABSTRAK
Pengoptimuman parameter kajian menggunakan rangsangan permukaan (RSM) merupakan kaedah yang dijangka dapat membantu penjimatan masa dan kos tindak balas keseluruhan jika dibandingkan dengan kaedah pengoptimuman secara tradisi. Dalam kajian ini, kaedah RSM digunakan untuk mengoptimumkan parameter tindak balas penghidrogenan LNR menggunakan sumber diimida daripada termolisis p-toluenasulfonil hidrazida (TSH) dalam pelarut o-xilena. Reka bentuk komposit putaran tengah (CCRD) menggunakan RSM digunakan dengan 3 parameter iaitu nisbah berat TSH: LNR, suhu dan masa tindak balas. Melalui reka bentuk ini, model kuadratik untuk peratusan penghidrogenan berjaya diperoleh. Model kuadratik ini adalah signifikan dengan pekali kolerasi iaitu 0.9177. Berdasarkan data ANOVA yang diperoleh, masa dan suhu tindak balas memberi kesan yang signifikan terhadap peratus penghidrogenan getah asli cecair berbanding faktor nisbah berat TSH: LNR. Keadaan optimum bagi tindak balas penghidrogenan ini adalah pada nisbah berat TSH: LNR, 1.41, masa tindak balas 2.22 jam dan suhu tindak balas $114.05^{\circ} \mathrm{C}$ dengan peratus penghidrogenan $81.83 \%$. Penggunaan RSM dalam penghasilan HLNR memudahkan kajian dalam memberikan keputusan dengan peratusan penghidrogenan yang dikehendaki menggunakan persamaan polinomial kuadratik yang diperoleh.
\end{abstract}

Kata kunci: Getah asli cecair (LNR); getah asli cecair terhidrogen (HLNR); kaedah rangsangan permukaan (RSM); reka bentuk komposit putaran tengah (CCRD); o-xilena

\section{ABSTRACT}

Optimization of research parameter using response surface methods (RSM) is expected to help save the overall time and cost of the reaction compared to traditional method of optimization. In this research, RSM is used for optimization of hydrogenation of LNR using diimide source from thermolysis of p-toluenesulfonyl hydrazide (TSH) in o-xylene solvent. Central composite rotatable design (CCRD) using RSM with 3 factors which are weight ratio TSH: LNR, reaction time and reaction temperature. Using this design, quadratic model for percentage of hydrogenation was obtained. This quadratic model was significant to the correlation coefficient of 0.9177. Based on ANOVA, the reaction time and reaction temperature were more significant on the percentage of hydrogenation of LNR compared to the weight ratio TSH: LNR. The optimum condition of the hydrogenation reaction was obtained at 1.41 weight ratio of TSH: LNR, reaction time of 2.22 h and reaction temperature of $114.05^{\circ} \mathrm{C}$ with $81.83 \%$ of hydrogenation. The use of RSM in HLNR preparation assist in the production of desired hydrogenation percentage based on the quadratic polynomial equation obtained.

Keywords: Central composite rotatable design (CCRD); hydrogenated liquid natural rubber (HLNR); liquid natural rubber (LNR); o-xylene; response surface methods (RSM)

\section{PENGENALAN}

Getah asli (NR) merupakan sumber asli yang diperoleh daripada pokok Hevea brasiliensis yang turut dikenali sebagai pokok getah. Struktur kimia bagi NR adalah cis1,4-poliisoprena $\left(\mathrm{C}_{5} \mathrm{H}_{8}\right)_{\mathrm{n}}$. NR merupakan salah satu sumber yang boleh diperbaharui dan digunakan secara meluas dalam industri pembuatan tayar, komponen kereta, pelekat, sarung tangan dan pelbagai jenis produk getah yang lain. Selain itu, ciri NR yang mempunyai sifat keelastikan dan kekuatan mekanik yang baik menjadikan ia tumpuan bagi penyelidik pada masa kini. Namun begitu, NR mempunyai kelemahan daripada segi ketahanan haba yang rendah dan mudah terdegradasi apabila terdedah kepada tekanan luar seperti ozon dan haba disebabkan kehadiran ikatan tidak tepu pada struktur tulang belakang NR (Samran et al. 2005).

Getah asli cecair (LNR) seringkali didefinisikan sebagai satu bentuk NR yang mempunyai mikrostruktur yang serupa tetapi mempunyai rantai polimer yang pendek dan mudah untuk berlaku penambahan kumpulan berfungsi atau kumpulan aktif baru ke dalam rantai polimer LNR (Nur Hanis Adila et al. 2015). Selain itu, Nor dan Ebdon (1998) melaporkan bahawa LNR mampu mengalir pada suhu bilik dan memudahkan proses pencampuran berlaku dalam kos pemprosesan yang lebih rendah berbanding NR. Modifikasi NR kepada LNR menghasilkan NR yang mempunyai rantai polimer yang lebih pendek dan berat molekul yang lebih rendah $\left(\mathrm{M}_{\mathrm{w}}<10^{5}\right)$ tidak mengubah struktur utama rantai poliisoprena. Proses modifikasi 
NR kepada LNR boleh dilakukan melalui kaedah redoks (Phinyocheep \& Duangthong 2000), pengoksidaan terma (Kargarzadeh et al. 2014), ozonolisis (Kodama et al. 2003) dan pengoksidaan fotopemeka (Ibrahim 1994).

Modifikasi kimia ke atas NR/LNR seperti penghidrogenan, pemvulkanan dan taut silang dijalankan bagi meningkatkan kebolehan getah daripada segi sifat fizikal seperti kestabilan haba, oksidatif dan degradasi yang disebabkan daripada radiasi (Nur Hanis Adila et al. 2017). Penghidrogenan NR merupakan salah satu modifikasi yang paling sesuai untuk mengatasi masalah degradasi pengoksidaan NR. Tindak balas penghidrogenan berlaku pada ikatan tidak tepu poliisoprena (Hinchiranan et al. 2006) dengan atom $H$ ditambahkan dalam rantai. Mahittikul et al. (2007) melaporkan penghidrogenan tanpa pemangkin menggunakan diimida yang dihasilkan secara in situ (Rajah 1). Diimida yang terhasil daripada proses termolisis $p$-toluenesulfonil hidrazida (TSH) menjadi sumber hidrogen dalam proses penghidrogenan tersebut. Penggunaan diimida dalam proses penghidrogenan menyebabkan penurunan pada ikatan ganda dua $\mathrm{C}=\mathrm{C}$ dan selektif terhadap kumpulan berfungsi tertentu. Hal ini menjadikan diimida sebagai jalan alternatif bagi penghidrogenan (Hunig et al. 1965). Kajian terkini oleh Naharullah et al. (2016) dan Nur Hanis Adila et al. (2015) terhadap penghidrogenan LNR dengan menggunakan sumber diimida iaitu TSH manakala (Hamizah et al. 2016) menjalankan penghidrogenan LNR menggunakan 2,4,6-trimetilbenzinsulfonil hidrazida ( $\mathrm{MSH})$ sebagai sumber diimida.

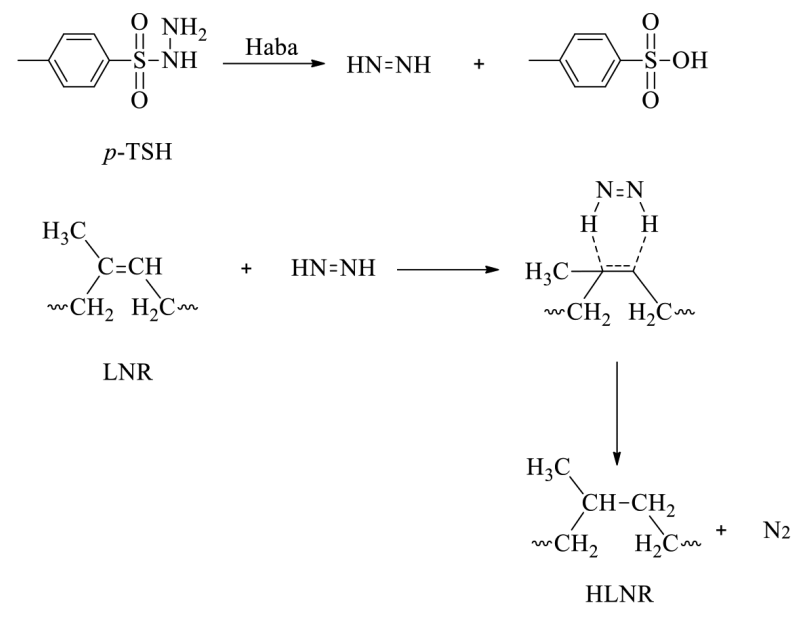

RAJAH 1. Skema tindak balas termolisis TSH dan penghidrogenan LNR menggunakan sumber diimida

Pengoptimuman bagi sesuatu tindak balas seringkali dijalankan secara konvensional dengan mengubah satu parameter tindak balas pada satu-satu masa. Kaedah ini tidak menunjukkan sebarang korelasi atau kaitan antara satu pemboleh ubah yang dikaji dengan pemboleh ubah yang lain (Lundstedt et al. 1998). Kaedah ini juga melibatkan penggunaan bahan kimia yang banyak dan menyebabkan pembaziran. Hal ini demikian kerana jumlah bahan kimia yang banyak diperlukan untuk mengkaji satu jenis parameter sahaja (Bezerra et al. 2008). Oleh itu, kaedah pengoptimuman parameter kajian yang paling inovatif pada masa kini adalah dengan menggunakan kaedah rangsangan permukaan (RSM). RSM merupakan satu teknik matematik dan statistik yang digunakan untuk menganalisis kesan perubahan pemboleh ubah (Myers \& Montgomery 2002) dalam tempoh masa yang minimum. RSM juga sering digunakan bagi pengoptimuman kerana ia dapat menentukan hubungan secara kuantitatif antara sesuatu gerak balas dengan parameter yang dikaji. RSM dapat didefinisikan sebagai perwakilan geometri yang diperoleh apabila sesuatu gerak balas diplotkan sebagai fungsi kepada parameter yang lain.

Dalam kajian ini, pengoptimuman penghidrogenan LNR menggunakan sumber diimida (TSH) dalam pelarut $o$-xilen untuk menghasilkan getah asli cecair terhidrogen (HLNR) dilakukan menggunakan RSM dengan reka bentuk komposit putaran tengah (CCRD) sebagai reka bentuk eksperimen untuk mengenal pasti hubungan antara gerak balas dengan beberapa parameter tindak balas. Parameter tindak balas yang dikaji adalah nisbah berat TSH:LNR, masa dan suhu tindak balas.

\section{BAHAN DAN KAEDAH}

\section{BAHAN}

Getah asli yang digunakan dalam kajian ini diperoleh daripada Institut Penyelidikan Getah Malaysia. Pelarut toluene (>99\%), o-xilena (>99\%) dan etanol $(95 \%)$ dibekalkan oleh R\&M Chemicals. Metilena biru (>95\%), ros Bengal (95\%), p-toluenasulfonil hidrazida (TSH) (97\%) diperoleh daripada Sigma Aldrich (Missouri, Amerika Syarikat).

\section{PENGHASILAN GETAH ASLI CECAIR (LNR)}

LNR disediakan menggunakan kaedah fotodegradasi (Kargarzadeh et al. 2014). Sebanyak 1 kg NR direndam dalam pelarut toluena sehingga mengembang. Kemudian, metanol (10 mL), ros Bengal $(0.10 \mathrm{~g})$ dan metilena biru (0.066 g) ditambah ke dalam campuran NR. Campuran kemudian didedahkan di bawah cahaya ultralembayung (UV) dan dikacau selama 12 hari pada 10-30 rpm. LNR yang terhasil kemudian diempar pada 6000 rpm untuk memisahkan gel yang terhasil semasa proses fotodegradasi

\section{REKA BENTUK UJI KAJI}

Penghidrogenan LNR dijalankan berdasarkan reka bentuk yang disusun menggunakan perisian Design Expert 7.1.5. Jadual 1 menunjukkan julat parameter dan tahap dalam CCRD. Reka bentuk ini menyumbang kepada pembentukan 20 eksperimen yang terdiri daripada 8 titik faktorial, 8 titik paksi dan 6 titik pusat ditunjukkan dalam Jadual 2 . Penghidrogenan dijalankan dengan menambah jumlah TSH 
yang berbeza ke dalam larutan LNR dalam pelarut $o$-xilena dengan nisbah 1:1 kepada 3:1 bagi TSH:LNR. Tindak balas dijalankan pada suhu $\left(110-130^{\circ} \mathrm{C}\right)$ dan masa tindak balas (1-8 jam). Hasil kemudian dituras dan pemendakan dijalankan bagi menyingkirkan TSH berlebihan. Hasil akhir dikeringkan dalam ketuhar vakum untuk menyingkirkan pelarut. Peratus penghidrogenan ditentukan menggunakan kiraan pengamiran spektrum ${ }^{1} \mathrm{H}$ NMR.

\section{KEPUTUSAN DAN PERBINCANGAN}

Model terbaik bagi pengoptimuman penghidrogenan getah asli cecair (HLNR) dijalankan berdasarkan CCRD. Pembentukan CCRD adalah berdasarkan tiga parameter iaitu nisbah berat TSH:LNR, masa dan suhu tindak balas. Nilai peratusan penghidrogenan sebenar dan ramalan yang diperoleh melalui RSM ditunjukkan dalam Jadual 2. Nilai ramalan ditentukan berdasarkan teknik pemasangan model yang menunjukkan nilai yang selari dengan nilai sebenar. Keputusan analisis varians (ANOVA) ditunjukkan dalam Jadual 3. Berdasarkan (1), model yang sesuai adalah model polinomial kuadratik dengan A adalah nisbah berat TSH:LNR, B ialah masa dan C ialah suhu tindak balas.
Peratus penghidrogenan $(\%)=+82.73-1.69 A$

$+10.58 B+3.71 C-4.98 A B+5.73 A C+1.71 B C$

$+4.81 A^{2}-0.72 B^{2}-4.99 C^{2}$

Model kuadratik yang diperoleh ini didapati mempunyai nilai pekali penentuan $\left(\mathrm{R}^{2}\right)$ yang tinggi iaitu 0.9177 yang bermaksud $91.77 \%$ daripada jumlah variasi dalam penemuan disebabkan oleh pemboleh ubah bebas. Model regrasi dengan nilai melebihi 0.9 bagi nilai $\mathrm{R}^{2}$ dianggap sebagai model yang mempunyai kolerasi yang tinggi. Selain itu, dalam kajian Hamzaoui et al. (2008) menyatakan nilai bahawa model empirikal yang sesuai dengan data sebenar boleh diperoleh apabila nilai $\mathrm{R}^{2}$ menghampiri nilai 1 adalah lebih bagus. Oleh itu, nilai $\mathrm{R}^{2}$ yang diperoleh dalam model regresi ini menunjukkan kesesuaian antara nilai ramalan dan nilai sebenar peratus penghidrogenan HLNR. Berdasarkan data ANOVA (Rajah 3), model ini didapati signifikan dengan nilai P, 0.0007 . Manakala nilai bagi lack of fit $(p=0.8716)$ dan ia tidak signifikan secara statistik. Nilai yang melebihi 0.05 menunjukkan bahawa model ini sesuai untuk analisis lanjut.

JADUAL 1. Julat parameter dan tahap dalam CCRD

\begin{tabular}{lccccc}
\hline \multirow{2}{*}{ Parameter } & \multicolumn{5}{c}{ Tahap } \\
\cline { 2 - 5 } & -2 & -1 & 0 & 1 & 2 \\
\hline Nisbah berat TSH:LNR, A (g) & 1.00 & 1.41 & 2.00 & 2.59 & 3.00 \\
Masa tindak balas, B (jam) & 1.00 & 1.61 & 2.50 & 3.39 & 4.00 \\
Suhu tindak balas, C $\left({ }^{\circ} \mathrm{C}\right)$ & 110.00 & 114.05 & 120.0 & 125.95 & 130.00 \\
\hline
\end{tabular}

JADUAL 2. Reka bentuk komposit putaran tengah bagi HLNR

\begin{tabular}{cccccc}
\hline \multirow{2}{*}{ No } & $\begin{array}{c}\text { Nisbah berat } \\
\text { TSH:LNR, A }(\mathrm{g})\end{array}$ & $\begin{array}{c}\text { Masa tindak balas, } \\
\mathrm{B}(\mathrm{jam})\end{array}$ & $\begin{array}{c}\text { Suhu tindak balas, } \\
\mathrm{C}\left({ }^{\circ} \mathrm{C}\right)\end{array}$ & \multicolumn{2}{c}{ Peratus penghidrogenan $(\%)$} \\
\cline { 5 - 6 } 2 & $2.59(1)$ & $3.39(1)$ & $114.05(-1)$ & Sebenar & Ramalan \\
3 & $2.00(0)$ & $2.50(0)$ & $120.00(0)$ & 82.34 & 74.59 \\
4 & $3.00(2)$ & $2.50(0)$ & $120.00(0)$ & 94.98 & 82.73 \\
5 & $2.59(1)$ & $1.61(-1)$ & $125.95(1)$ & 80.68 & 83.48 \\
6 & $2.00(0)$ & $2.50(0)$ & $130.00(2)$ & 73.76 & 74.86 \\
7 & $2.59(1)$ & $3.39(1)$ & $125.95(1)$ & 98.33 & 96.89 \\
8 & $2.00(0)$ & $2.50(0)$ & $120.00(0)$ & 71.96 & 82.73 \\
9 & $2.00(0)$ & $2.50(0)$ & $120.00(0)$ & 85.21 & 82.73 \\
10 & $1.41(-1)$ & $1.61(-1)$ & $125.95(1)$ & 66.84 & 64.22 \\
11 & $2.00(0)$ & $2.50(0)$ & $110.00(-2)$ & 64.99 & 62.40 \\
12 & $1.41(-1)$ & $3.39(1)$ & $114.05(-1)$ & 99.91 & 99.39 \\
13 & $1.41(-1)$ & $3.39(1)$ & $125.95(1)$ & 97.27 & 98.77 \\
14 & $2.59(1)$ & $1.61(-1)$ & $114.05(-1)$ & 67.25 & 66.81 \\
15 & $2.00(0)$ & $2.50(0)$ & $120.00(0)$ & 90.40 & 82.73 \\
16 & $1.41(-1)$ & $1.61(-1)$ & $114.05(-1)$ & 69.20 & 71.70 \\
17 & $2.00(0)$ & $2.50(0)$ & $120.00(0)$ & 85.90 & 82.73 \\
18 & $2.00(0)$ & $1.00(-2)$ & $120.00(0)$ & 62.98 & 62.89 \\
19 & $2.00(0)$ & $2.50(0)$ & $120.00(0)$ & 80.31 & 82.73 \\
20 & $2.00(0)$ & $4.00(2)$ & $120.00(0)$ & 99.88 & 98.48 \\
\hline
\end{tabular}

*eksperimen \#1 diabaikan 
JADUAL 3. Data ANOVA bagi model kuadratik penghidrogenan LNR

\begin{tabular}{|c|c|c|c|c|c|}
\hline Sumber & Jumlah kuasa dua & Darjah kebebasan & Min kuasa dua & Nilai F & Nilai P \\
\hline Model & 2708.82 & 9 & 300.98 & 11.14 & 0.0007 \\
\hline Nisbah berat bagi TSH:LNR, A & 25.59 & 1 & 25.59 & 0.95 & 0.3558 \\
\hline Masa tindak balas, B & 1529.09 & 1 & 1529.09 & 56.61 & $<0.0001$ \\
\hline Suhu tindak balas, $\mathrm{C}$ & 187.47 & 1 & 187.47 & 6.94 & 0.0272 \\
\hline $\mathrm{AB}$ & 198.30 & 1 & 198.30 & 7.34 & 0.0240 \\
\hline $\mathrm{AC}$ & 262.78 & 1 & 262.78 & 9.73 & 0.0123 \\
\hline $\mathrm{BC}$ & 23.50 & 1 & 23.50 & 0.87 & 0.3753 \\
\hline $\mathrm{A}^{2}$ & 194.39 & 1 & 194.39 & 7.20 & 0.0251 \\
\hline $\mathrm{B}^{2}$ & 7.19 & 1 & 7.19 & 0.27 & 0.6184 \\
\hline $\mathrm{C}^{2}$ & 340.86 & 1 & 340.86 & 12.62 & 0.0062 \\
\hline Sisa & 243.09 & 9 & 27.01 & - & - \\
\hline Lack-of-fit & 46.07 & 4 & 11.52 & 0.29 & 0.8716 \\
\hline Ralat tulen & 197.02 & 5 & 39.40 & - & - \\
\hline Jumlah & 2951.90 & 18 & - & - & - \\
\hline
\end{tabular}

Kesan parameter pada peratus penghidrogenan ditunjukkan dalam Rajah 2. Graf dalam Rajah 2a dibina dengan memplot nilai tengah parameter iaitu pada nisbah berat TSH:LNR (2:1), masa (2.50 jam) dan suhu tindak balas $\left(120^{\circ} \mathrm{C}\right)$. Kesan nisbah berat TSH:LNR dan masa pada suhu yang ditetapkan pada $120^{\circ} \mathrm{C}$ dalam Rajah 2a menunjukkan peratus penghidrogenan adalah maksimum (99.91\%) pada nisbah berat yang kecil dan masa tindak balas yang lama (3.39 jam). Manakala peratus penghidrogenan yang minimum (62.98\%) diperoleh apabila penghidrogenan dilakukan pada nisbah berat yang kecil dan masa yang singkat (1.61 jam). Melalui data ini, masa tindak balas yang lama membawa kepada peratusan penghidrogenan yang lebih tinggi sekiranya sumber diimida yang digunakan masih kekal dalam sistem tindak balas. Selain itu, keterlarutan TSH dalam pelarut $o$-xilena lebih efisien berbanding dalam pelarut toluena dan menyebabkan penghasilan diimida untuk bertindak balas dengan ikatan ganda dua $\mathrm{C}=\mathrm{C}$ lebih mudah (Mahittikul et al. 2007). Oleh itu, dalam kes ini, nisbah berat TSH:LNR tidak memberi kesan yang signifikan terhadap peratus penghidrogenan. Nisbah berat TSH:LNR pada 1.41:1 dalam pelarut $o$-xilena adalah mencukupi untuk proses penghidrogenan.

Rajah 2(b) menunjukkan kesan nisbah berat TSH:LNR dan suhu pada masa tindak balas yang ditetapkan iaitu 2.50 jam. Peratus penghidrogenan adalah tinggi apabila nisbah berat TSH:LNR dan suhu tinggi (2.59:1 dan $125.95^{\circ} \mathrm{C}$ ). Namun begitu, kedua-dua parameter ini tidak memberikan kesan yang begitu signifikan terhadap peratus penghidrogenan LNR. Nilai peratus penghidrogenan tertinggi yang boleh dicapai berdasarkan dua parameter ini adalah sekitar 90-91\% berbanding korelasi pembolehubah yang lain iaitu sehingga $99.91 \%$. Walau bagaimanapun, peratus penghidrogenan paling minimum direkodkan pada nisbah berat TSH:LNR yang tinggi pada suhu yang singkat. Manakala, pada suhu yang rendah, termolisis TSH untuk menghasilkan diimida bagi proses penghidrogenan sukar untuk berlaku disebabkan sumber tenaga yang dibekalkan rendah. Oleh itu, lebih besar nisbah TSH:LNR yang diperlukan untuk mencapai peratus penghidrogenan yang tinggi.

Rajah 2(c) menunjukkan korelasi antara masa dengan suhu tindak balas pada nisbah berat TSH:LNR yang ditetapkan iaitu 1.41:1. Peratus penghidrogenan paling tinggi diperoleh apabila masa tindak balas yang lama (3.39 jam) digunakan pada suhu yang tinggi $\left(125.95^{\circ} \mathrm{C}\right)$. Manakala peratus penghidrogenan yang minimum diperoleh pada masa yang singkat (1.61 jam) dan suhu yang rendah $\left(110^{\circ} \mathrm{C}\right)$. Selain itu, peratus penghidrogenan yang minimum juga direkodkan apabila penghidrogenan dilakukan pada suhu yang tinggi $\left(125.95^{\circ} \mathrm{C}\right)$ dan masa yang singkat (1.61 jam). Data ini menunjukkan bahawa masa memberikan kesan yang signifikan terhadap peratus penghidrogenan HLNR berbanding suhu. Ini adalah kerana, pada masa penghidrogenan yang lama, sumber diimida yang terdapat dalam sistem akan bertindak balas sepenuhnya dengan ikatan ganda dua yang terdapat dalam rantai LNR. Julat suhu yang dibekalkan pula adalah mencukupi bagi proses termolisis TSH untuk menghasilkan diimida.

Model yang diperoleh berdasarkan RSM ini boleh digunakan untuk meramal peratusan penghidrogenan bagi sebarang keadaan tindak balas dalam julat eksperimen. Persamaan polinomial kuadratik (1) yang telah diberikan oleh perisian membolehkan penyelidik untuk menghasilkan HLNR dengan peratus penghidrogenan yang dihendaki. Hal ini berbeza apabila kaedah konvensional yang tidak mampu untuk meramal peratusan penghidrogenan yang terhasil digunakan. Berdasarkan kajian yang telah dijalankan oleh Nur Hanis Adila et al. (2015), penghidrogenan LNR dapat meningkatkan sifat kestabilan termanya. Oleh itu, peratusan penghidrogenan yang berlainan akan memberikan sifat terma yang berbeza mengikut keperluan dalam aplikasi yang tertentu. 


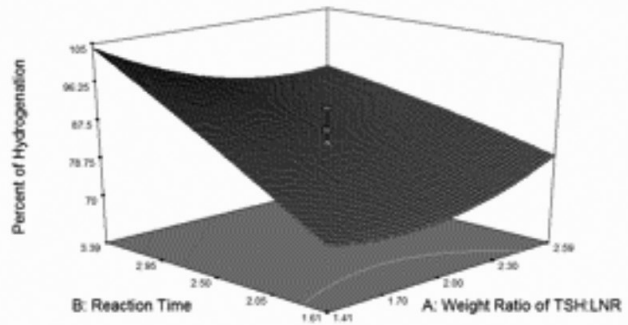

(a)

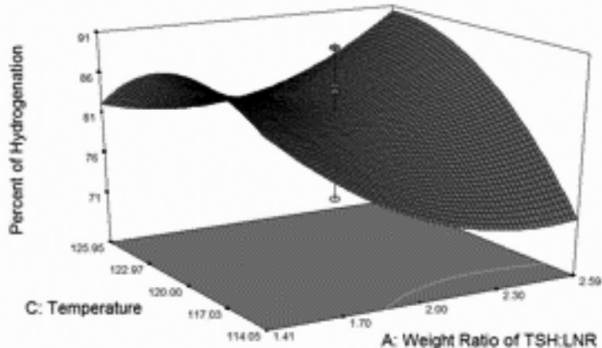

(b)

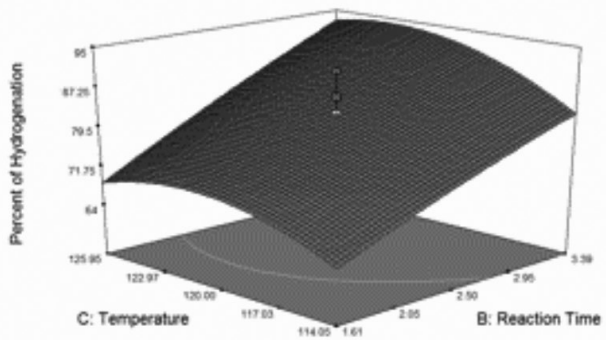

(c)

RAJAH 2. Plot 3D respon permukaan (a) nisbah berat TSH:LNR dengan masa tindak balas (b) nisbah berat TSH:LNR dengan suhu tindak balas (c) masa tindak balas dengan suhu tindak balas

\section{PENCIRIAN GETAH ASLI CECAIR TERHIDROGEN (HLNR)}

Pencirian menggunakan FTIR telah dijalankan ke atas mikrostruktur LNR dan HLNR dan perbandingan antara kedua-dua spektrum ditunjukkan dalam Rajah 3. Puncak serapan yang penting dalam spektrum FTIR bagi LNR ialah serapan pada $3000-2850 \mathrm{~cm}^{-1}$ (regangan C-H $\left.s p^{3}\right), 1664 \mathrm{~cm}^{-1}$ (regangan $\mathrm{C}=\mathrm{C}$ ) dan pada $834 \mathrm{~cm}^{-1}$ (pembengkokan olefinik C-H). Selepas penghidrogenan dijalankan, berlakunya penambahan pada keamatan bagi puncak regangan $\mathrm{C}-\mathrm{H} s p^{3}$ kerana terdapat peningkatan pada kumpulan alkana. Keamatan bagi dua lagi puncak menunjukkan pengurangan disebabkan oleh bilangan $\mathrm{C}=\mathrm{C}$ dan olefinik C-H selepas penghidrogenan dijalankan. Nilainilai puncak serapan ini sama seperti yang dilaporkan oleh Nur Hanis Adila et al. (2015).
Perbandingan spektrum ${ }^{1} \mathrm{H}$ NMR bagi LNR dan $99.91 \%$ HLNR dapat dilihat dalam Rajah 4. Spektrum NMR bagi LNR menunjukkan isyarat pada anjakan kimia 1.71, 2.09 dan 5.16 ppm dengan masing-masing merujuk kepada kehadiran kumpulan metil tak tepu $\left(\mathrm{R}-\mathrm{CH}_{3}\right)$, metilena tak tepu (R-CH $\left.-\mathrm{R}^{\prime}\right)$ dan proton olefinik (R-CH=C-R'). Selepas penghidrogenan dijalankan, berlakunya sedikit pengurangan pada keamatan bagi puncak proton olefinik $(5.16 \mathrm{ppm})$ disebabkan oleh pengurangan bilangan proton pada karbon tak tepu. Selain daripada itu, pengurangan turut berlaku pada keamatan bagi puncak metil tak tepu (1.71 ppm) dan metilena tak tepu (2.09 ppm) selepas proses penghidrogenan. Tambahan pula, penghidrogenan ini juga menyebabkan munculnya beberapa isyarat baru iaitu pada julat 0.8-1.4 ppm yang menunjukkan kehadiran

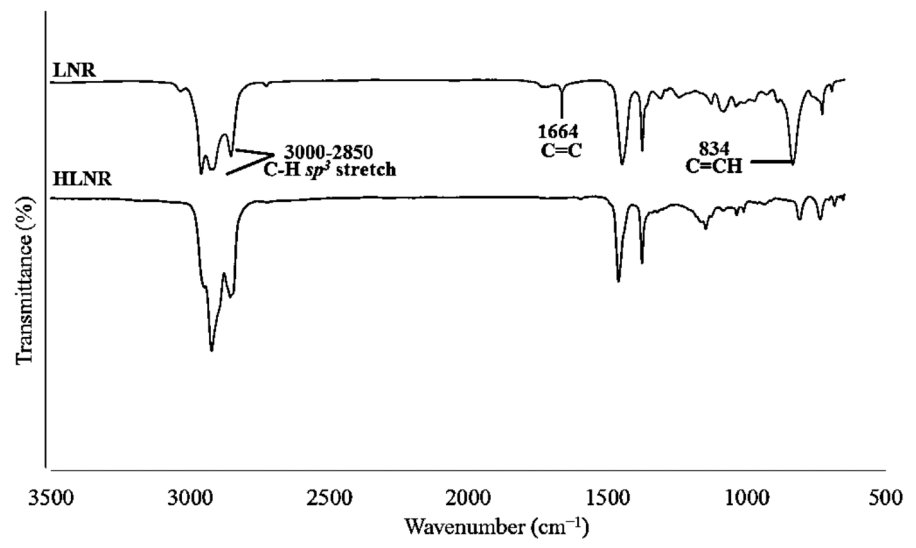

RAJAH 3. Spektrum FTIR bagi LNR dan 99.91\% HLNR 

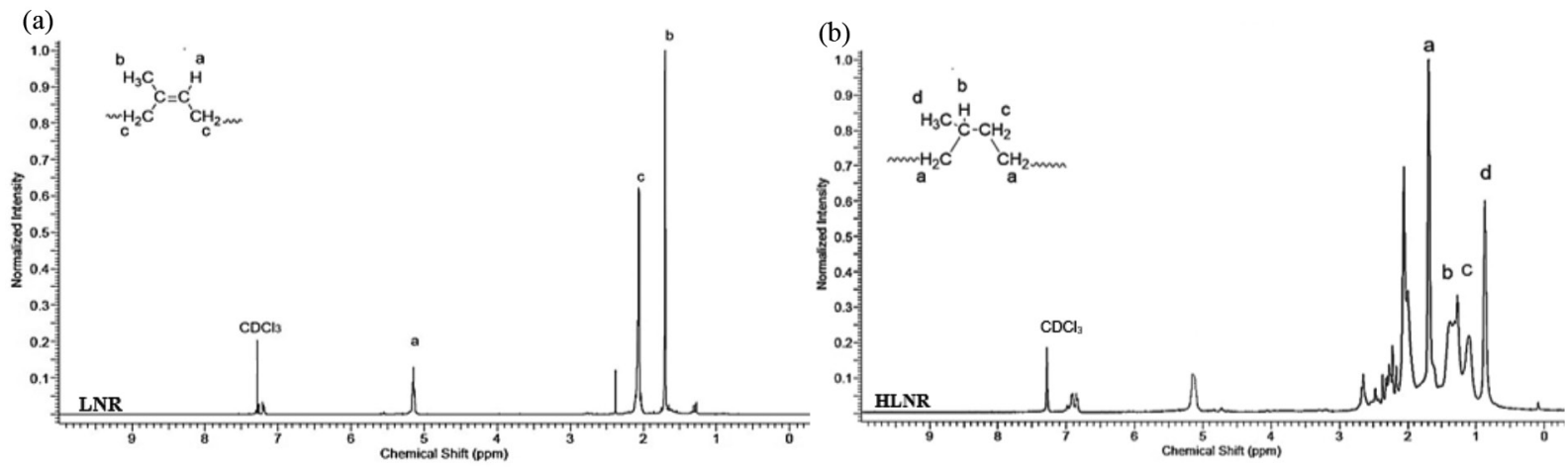

RAJAH 4. Spektrum ${ }^{1} \mathrm{H}$ NMR bagi (a) LNR dan (b) HLNR

metilena (- $\left.\mathrm{CH}_{2}-\right)$ dan metil (- $\left.\mathrm{CH}_{3}\right)$. Isyarat pada $7.24 \mathrm{ppm}$ merujuk kepada $\mathrm{CDCl}_{3}$ yang berperanan sebagai bahan pelarut bagi sampel.

\section{KESIMPULAN}

Pengoptimuman bagi penghidrogenan getah asli cecair berjaya dilakukan menggunakan kaedah rangsangan permukaan (RSM) berbanding menggunakan kaedah konvensional. Model kuadratik berjaya dibangunkan bagi tindak balas penghidrogenan LNR menggunakan sumber diimida. Nilai uji kaji dan nilai yang diramalkan adalah signifikan dengan pekali korelasi 0.9177. Berdasarkan data ANOVA, masa dan suhu tindak balas memberikan kesan yang signifikan terhadap peratus penghidrogenan HLNR. Keadaan optima bagi penghidrogenan LNR adalah pada keadaan nisbah berat TSH:LNR 1.41, masa 2.22 jam dan suhu tindak balas $114.05^{\circ} \mathrm{C}$ dengan peratus penghidrogenan $81.83 \%$.

\section{PENGHARGAAN}

Jutaan terima kasih dirakamkan untuk Universiti Kebangsaan Malaysia (UKM) atas geran penyelidikan FRGS/1/2016/STG01/UKM/02/4 dan GUP-2017-004 dan Pusat Penyelidikan dan Instrumentasi (CRIM) di UKM untuk kemudahan yang diberikan.

\section{RUJUKAN}

Bezerra, M.A., Santelli, R.E., Oliveira, E.P., Villar, L.S. \& Escaleira, L.A. 2008. Review: Response surface methodology (RSM) as a tool for optimization in analytical chemistry. Talanta 76: 965-977. doi: 10.1016/j.talanta.2008.05.019.

Hamizah, M.R., Nur Hanis Adila, A., Naharullah, J. \& Siti Fairus, M.Y. 2016. Mild approach for non-catalytic hydrogenation of liquid natural rubber using MSH as diimide source. Bulletin of the Korean Chemical Society 37: 797-801.

Hamzaoui, A.H., Jamoussi, B. \& M'nif, A. 2008. Lithium recovery from highly concentrated solutions: Response surface methodology (RSM) process parameters optimization. Hydrometallurgy 90(1): 1-7.

Hinchiranan, N., Prasassarakich, P. \& Rempel, G.L. 2006. Hydrogenation of synthetic Cis-1,4-poly(isoprene) and natural rubber catalyzed by $[\operatorname{Ir}(\mathrm{COD}) \mathrm{py}(\mathrm{Pcy} 3) \mathrm{PF} 6$. Journal of Applied Polymer Science 100: 4219-4233.
Hunig, S., Muller, H.R. \& Their, W. 1965. The chemistry of diamine. Angewandte Chemie - International Edition in English 4: 271-280.

Ibrahim, A. 1994. Liquid Natural Rubber : Preparation and Application. Progress in Pacific Polymer Science 3: 351-365.

Kargarzadeh, H., Ahmad, I., Abdullah, I., Thomas, R., Dufresne, A., Thomas, S. \& Hassan, A. 2014. Functionalized liquid natural rubber and liquid epoxidized natural rubber: A promising green toughening agent for polyester. Journal of Applied Polymer Science 5: 1-15. doi:10.1002/app.41292.

Kodama, S., Nishi, K. \& Furukawa, M. 2003. Preparation of low molecular weight natural rubber by ozonolysis of high ammonia latex. Journal of Rubber Research 6(3): 153-163.

Lundstedt, T., Seifert, E., Abramo, L., Thelin, B., Nystrom, A., Pettersen, J. \& Bergman, R. 1998. Experimental design and optimization. Chemometrics and Intelligent Laboratory Systems 42(1): 3-40.

Mahittikul, A., Prasassarakich, P. \& Rempel, G.L. 2007. Noncatalytic hydrogenation of natural rubber latex. Journal of Applied Polymer Science 103: 2885-2895.

Myers, R.H. \& Montgomery, D.C. 2002. Response Surface Methodology. New York: John Wiley and Sons.

Naharullah, J., Mohd Jefri, M.Y., Ibrahim, A. \& Siti Fairus, M.Y. 2016. Synthesis, characterization and properties of hydrogenated liquid natural rubber. Rubber Chemistry and Technology 89(2): 227-239.

Nor, H.M. \& Ebdon, J.R. 1998. Telechelic liquid natural rubber : A review. Progress in Polymer Science 23: 143-177. doi:10.1016/S0079-6700(97)00028-2.

Nur Hanis Adila, A., Hamizah, M.R. \& Siti Fairus, M.Y. 2017. Epoxidation and hydroxylation of liquid natural rubber. Sains Malaysiana 46(3): 485-491.

Nur Hanis Adila, A., Naharullah, J., Mohd Jefri, M.Y. \& Siti Fairus, M.Y. 2015. Studies on hydrogenation of liquid natural rubber using diimide. International Journal of Polymer Science 243028: 1-6.

Phinyocheep, P. \& Duangthong, S. 2000. Ultraviolet-curable liquid natural rubber. Journal of Applied Polymer Science 78: $1478-1485$.

Samran, J., Phinyocheep, P., Daniel, P. \& Kittipom, S. 2005. Hydrogenation of unsaturated rubbers using diimide as a reducing agent. Journal of Applied Polymer Science 95(1): $16-27$.

Fazira Firdaus, Nur Hanis Adila Azhar, Mohamad Shahrul Fizree Idris \& Siti Fairus M. Yusoff 
Pusat Pengajian Sains Kimia dan Teknologi Makanan Fakulti Sains dan Teknologi

Universiti Kebangsaan Malaysia

43600 UKM Bangi, Selangor Darul Ehsan

Malaysia

Siti Fairus M. Yusoff

Polymer Research Centre (PORCE)

Fakulti Sains dan Teknologi

Universiti Kebangsaan Malaysia

43600 UKM Bangi, Selangor Darul Ehsan

Malaysia
*Pengarang untuk surat-menyurat; email: sitifairus@ukm.edu.my

Diserahkan: 2 Jun 2017

Diterima: 24 Oktober 2017 